\title{
FLORA DIVERSITY OF FIELD FOREST PATCHES IN LANDSCAPES WITH VARIED GEOMORPHOLOGICAL UNITS AND LAND USE IN POLAND
}

\author{
GAMRAT, R. ${ }^{*}{ }^{*}$ - GALCZYŃSKA, M. $^{2}$ \\ ${ }^{I}$ Department of Environmental Management, West Pomeranian University of Technology, \\ Stowackiego 17, PL-71-434 Szczecin, Poland \\ ${ }^{2}$ Department of Bioengineering, West Pomeranian University of Technology, Stowackiego 17, \\ PL-71-434 Szczecin, Poland \\ (e-mail: Malgorzata.Galczynska@ zut.edu.pl; phone: +48-91-449-6322) \\ *Corresponding author \\ e-mail: Renata.Gamrat@zut.edu.pl; phone: +48-91-449-6343
}

(Received $21^{\text {st }}$ Nov 2020; accepted $8^{\text {th }}$ Feb 2021)

\begin{abstract}
A diverse terrain is one of the essential natural features of a balanced landscape and the specific features of its geomorphological units (sandur, moraine) contribute to regional diversity. The present work describes research designed to verify the hypothesis that the diversity of flora in the ecotone zone of woodland in Poland relates to variability both in the terrain and in land use. By using phytoindication it was possible to assess differentiation in the surfaces under study. It was found that land use (agricultural and forest use) was responsible for the occurrence of a positive interrelationship between trophy and synanthropisation values, no matter what kind of geomorphological unit there was. On the basis of the species composition in the areas under research, within the ecotone zone of woodland, it was established that in the area within moraine which had previously been used agriculturally there was a cumulation of species due to habitat diversity in ecological niches resulting from the terrain, the amount of mineral nutrients in the soil and a large amount of, in particular, native and neutral species in the gene pool.
\end{abstract}

Keywords: sandur, moraine, ecological indicators, agricultural land

Abbreviations: s: Object is located on the sandur; $\mathrm{m}$ : Object is located on the moraine; fd: Object is located in the area previously used for agriculture; ft: Object is located in a previously forested area.

\section{Introduction}

Forest patches within the agricultural landscape are considered valuable due to their production or protective functions (lumber, regulation of water and temperature conditions on the fields) as well as ecological function (maintaining phytodiversity, including that of forest species in areas related to agrocenosis), aesthetic and landscape values (Jamoneau et al., 2012; Foli et al., 2015; Decocq et al., 2016; Hladnik et al., 2020). A particular role in maintaining phytodiversity is played by the most external part of forest patches, i.e. the ecotone zone (Chabrerie et al., 2013; Gamrat and Gałczyńska, 2014; Skrajna, 2020). The gene pool of seeds of the plant species found in that area depends on various factors, among others, the shape and size of the area, the length of borderline and the type of tree stand (Esseen et al., 2016).

The effect of tree stands on improving the natural features of sustainable landscape is especially valuable with respect to anthropogenic areas - a category encompassing arable fields (Forrest et al., 2015; Proesmans et al., 2019). Apart from the effect of anthropic pressure, the species composition of these ecosystems is determined by landscape features such as, for example, location within the specific geomorphological units such 
as sandur or moraine (Batary et al., 2011; Stepanovich, 2019; Majewski and Marszałek, 2020). Topography of the surface determines the available soil moisture regimes and nutrient gradients contributing to differentiation of habitat conditions, and thus plant composition (Jia et al., 2015).

The previous form of use of forest patches as an afforested production area or arable field may affect the species composition of the area through modifications of the vertical structure of flora or habitat mosaic due to specific characteristics of land use (Chabrerie et al., 2013; Lõhmus et al., 2014; Jia et al., 2019).

The present paper shows the effects of the two most essential factors consequential for the species composition of the ecotone zone of forest patches, i.e. topography (Jia et al., 2015) and the previous form of land use (Haddad et al., 2015). Research was conducted to verify the thesis stipulating that flora diversity in the ecotone zone of forest patches within sandur is lower than that within the moraine area. It was also stipulated that previous agricultural use of forest patches favours diversity of herbaceous synanthropic species. The said research fills the knowledge gap in terms of previous use of the analysed ecosystem in various geomorphological units. The increasing steppe formation on agricultural lands (Baude et al., 2019) may be a crucial factor in selecting the adequate management strategy of such landscapes to maintain biodiversity of fields affected by drought (Liu et al., 2020). The ecological factors affecting the fields with heavily dried surface layer of soil may be comparable to the factors determining biocenoses on sandur areas. The aim of the studies is to raise awareness of the impact of factors such as the type of geomorphological unit and prior use of land - covered at present with forest patches on their phytodiversity.

\section{Material and Methods}

\section{Study area}

During 2011-2013, floristic and phytosociological research was carried out in forest patches in their outer ecotone zone within the range of ground moraine and sandur (the GPS coordinates of the central part of the studies areas of maps, respectively $\mathrm{N}$

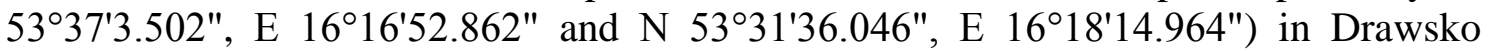
Lakeland in West Pomeranian province in N-W Poland (Fig. 1). The detailed analysis concerned the outermost part of the ecotone zone in contact with the surroundings. The terrain floristic research included three growing seasons in the subsequent years of the study, i.e. from April to September in 2011, 2012 and 2013.

The most significant features determining a forest, as well as affecting the flora composition, are origin - presence on the previously afforested areas or those not classified as a forest (Haddad et al., 2015; Chazdon et al., 2016), and location of the analysed objects on different geomorphological units (Jia et al., 2015; Stepanovich, 2019).

The analysed forest patches were of different origin (the objects previously used as forest or arable lands) and geomorphological location. The objects within the moraine plain were labelled " $m$ ", and those located within sandur as "s". In the present paper, the following abbreviations are used: "field-forest" / (the present forest patches area was used as agriculture fields in 1948), "fd" (field) or "forest-forest" (the present forest patches area was used as a forest in 1948) and " $\mathrm{ft}$ " (forest). The previous use of the analysed objects as forest or field was confirmed with archive aerial photographs taken in 1947-48. The geomorphological location of the forest patches under analysis was confirmed with 
geomorphological maps. The soil granulometric composition on which the studied forest patches were located was read from the soil maps.

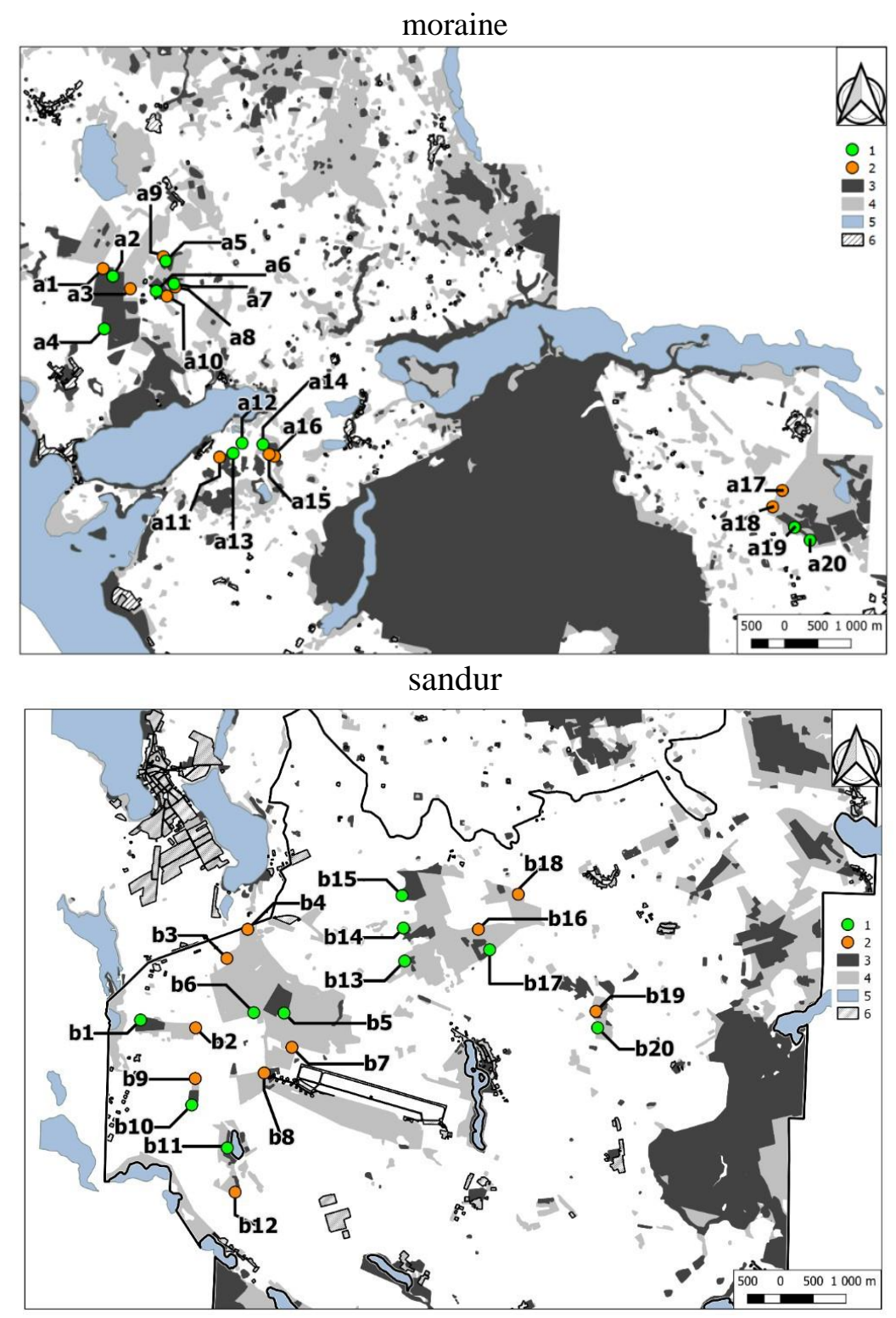

Figure 1. Location of studied forest patches on moraine and sandur. 1: field-forest research stand (the present forest patches area was used as agriculture fields in 1948), 2: forest-forest research stand (the present forest patches area was used as a forest in 1948), 3: forest-forest areas (areas used as forest in 1948), 4: field-forest areas (areas used as agriculture fields in

1948), 5: water, 6: build area

In the analysed forest patches, predominant was fresh mixed forest with a significant share of approx. 56-year-old pine trees Pinus sylvestris L. (mean value, Table 1). The height of the trees ranged from 8 to $12 \mathrm{~m}$. The studies were conducted on 6 fragments of forest patches (both on the moraine and sandur areas) located within or only in some part in arable lands, specifically wheat farming. The elevations of the rolling moraine plains ranged from $150 \mathrm{~m}$ to $180 \mathrm{~m}$ asl, and on the sandur area about $140 \mathrm{~m}$ asl. 
Table 1. Age of the stands at the examined points

\begin{tabular}{|c|c|c|}
\hline $\begin{array}{c}\text { Geomorphological } \\
\text { units }\end{array}$ & Land use & Number of object and age of the pine stand \\
\hline moraine & field-forest & $\begin{array}{c}\text { a1 - 55, a3 - 68, a } 7-55 \text {, a } 9-60, \text { a } 10-66, \text { a } 11-40, \text { a } 15-55 \text { (and } \\
\text { Betula pendula), a16 - } 25 \text { (and Fagus sylvatica), a17 - 52, a18 - 52 } \\
\text { a2 - 90, a4 - 5, a5 - 110, a6 - 50, a12 - 50, a } 8-90, \text { a13 - 70, a14 - } 110 \\
\text { (and Fagus sylvatica), a19-85, a20 - 30 }\end{array}$ \\
\hline sandur & field-forest & $\begin{array}{c}\mathrm{b} 7-56, \mathrm{~b} 8-52, \mathrm{~b} 2-25, \mathrm{~b} 3-55, \mathrm{~b} 4-55, \mathrm{~b} 9-60, \mathrm{~b} 12-56, \mathrm{~b} 16-46 \\
\text { (and Picea abies), b18 - } 25 \text { (and Betula pendula), b19-50 } \\
\mathrm{b} 1,20-66,20 \text { (and Betula pendula), b5 - 73, b6 - 73, b10 - 80, b11 - } \\
111, \mathrm{~b} 13-12, \mathrm{~b} 14-25, \mathrm{~b} 15-45, \mathrm{~b} 17-46\end{array}$ \\
\hline
\end{tabular}

a: objects located on the moraine, b: objects located on the sandur

\section{Physical features of ecotone zones}

Within the area of the selected forest patches, the ecotone zones of a width of $10 \mathrm{~m}$ and length of $20 \mathrm{~m}$ were analysed (Gamrat and Gałczyńska, 2014). Prior to the selection of the said areas and their size, terrain studies were conducted providing the analysis of plant structure, diameter at breast height of trees (comparable to the diameter results) and species diversity of trees (domination of Pinus sylvestris L.). Flora was categorised according to the vertical structure: the highest layer was constituted by the trees (a), the layer with lower location - shrubs and tree saplings (b), the layer with even lower location - herbaceous species (c), and the ground or arboreal level - mosses and lichens (d) (Table A1). Legally protected species were distinguished among the identified flora (JL, 2014).

On both geomorphological units, i.e. sandur and moraine, 40 phytosociological releve's were taken using the classic Braun-Blanquet method, allowing for the determination of the degree of surface coverage according to a 7-step scale following Dzwonko (2008) from 5 to $\mathrm{r}$. The calculated constancy values and that of the coverage coefficient for 10 phytosociological releve's (S-D) are synthesized in Table Al, presenting data of the constancy and coefficient of the identified communities (Matuszkiewicz, 2017). The selected area of each releve's was $200 \mathrm{~m}^{2}$.

\section{Features of ecological indicators}

For the purpose of the assessment of the degree of flora transformation, according to the identified geographical-historical groups, the synanthropization index ( $\mathrm{St}$ ) was calculated following Wysocki and Sikorski (2002), according to the formula:

$$
\text { St }=\frac{\mathrm{Ap}+\mathrm{A}}{\mathrm{C}} \cdot 100 \%
$$

where St is the synanthropization index; Ap is the number of apophyte species (native plants that entered the habitats changed by man); $\mathrm{A}$ is the number of anthropophyte species (foreign plants); $\mathrm{C}$ is the total number of all plant species.

This index identifies total transformation in the vegetation cover due to human activity (anthropic pressure). This process is manifested by the displacement of native species which are replaced by foreign or cosmopolitan elements (Stepanovich, 2019) or their quantitative transformation within the sociological structure. 
Flora is an ecological indicator of numerous changes taking place in the environment. In Central Europe, the commonly accepted method of assessing the habitats with the use of habitat preference of flora is the Ellenberg scale (Ellenberg et al., 1991). For the purpose of verification of the habitat conditions, selected values of the percentage share of ecological groups were calculated for the found flora, i.e., acidity $(\mathrm{pH})$ and nitrogen content (Trophy) in soil (Table 2).

Table 2. Numerical indicators determining flora's preferences according to the $\mathrm{pH}$ and nitrogen content in soil

\begin{tabular}{|c|c|c|}
\hline No & Soil acidity $(\mathrm{pH})$ value & Trophy value \\
\hline 1 & $\begin{array}{l}\text { strong indicator of acidity, never occur very } \\
\text { weakly acidic to alkaline soils }\end{array}$ & habitats most poor in nitrogen \\
\hline 2 & habitats intermediate between 1 and 3 & habitats intermediat \\
\hline 3 & indicator of acidity on acid soils rarely neutral & $\begin{array}{l}\text { habitat poor in nitrogen more than average } \\
\text { fertile }\end{array}$ \\
\hline 4 & habitats intermediate between 3 and 5 & habitats intermediate between 3 and 5 \\
\hline 5 & $\begin{array}{l}\text { habitats strongly acidified, at neutral and alkaline } \\
\text { soils }\end{array}$ & an average of habitats rich in nitrogen \\
\hline 6 & habitats intermediate between 5 and 7 & habitats intermediate between 5 and 7 \\
\hline 7 & $\begin{array}{l}\text { weaker indicator of acidity or alkalinity indicator } \\
\text { of poor, never occurs on strongly acidic soils }\end{array}$ & often to be rich in nitrogen positions \\
\hline 8 & habitats between 7 and 9 & habitats rich in nitrogen \\
\hline 9 & ratio of calcium to the soil very rich in calcium & habitats excessively rich in nitrogen \\
\hline
\end{tabular}

The possibility of spreading plant species was analyzed after Chmiel (1993), classifying the species into three synanthropodynamic groups. This classification included the following species: native (Native) - species that are very poorly spreading and endangered due to the destruction of their habitats, neutral (Neutral) - species poorly spreading and occurring only in habitats appropriate for them, invasive (Invasive) rapidly spreading and colonizing species other than their own habitats.

The natural values of the flora were determined by average values of the natural valorization index (Valorisation) were calculated according to the modified Oświt method (Gamrat et al., 2019 after Oświt, 2000, Table 3).

Table 3. Values of the natural classification of flora

\begin{tabular}{c|c|c|c|c|c}
\hline No & Values & Terms & No & Values & Terms \\
\hline 1 & $<1.4$ & very low & 6 & $3.1-3.4$ & measures high \\
2 & $1.5-1.8$ & medium low & 7 & $3.5-3.8$ & high \\
3 & $1.9-2.2$ & low & 8 & $3.9-4.2$ & very high \\
4 & $2.3-2.6$ & moderate & 9 & $4.3-4.6$ & eminent \\
5 & $2.7-3.0$ & medium moderate & 10 & $>4.6$ & unique \\
\hline
\end{tabular}

\section{Statistical analysis}

The results of the research on the indices characterising the habitat properties of the vegetation and the number of synanthropodynamic groups were subjected to two-factor variance analysis (1st factor - the form of the terrain - 2 levels, 2nd factor - land use - 2 levels). Also analysed was the correlation between selected indices (trophy, soil $\mathrm{pH}$ and valorisation) and those of the remaining research parameters, which, as regards the factors 
tested, were significantly different (synanthropisation index, total number of species, including native, invasive and neutral). The significance of differences between the mean values was calculated based on of Tukey's t- test with significance level $\alpha=0.05$. The calculations were performed by means of the Statistica 10 program.

\section{Results}

In the forest patches area, within the ground moraine and sandur, in the ecotone zone, 213 plant species were found, including 15 tree species, 12 species of shrubs, 7 lichens and 4 mosses (Table Al).

There were 5 partial protected species in the study area, including 3 mosses, 1 tree and 1 herbaceous plant. These species were found on prior forested forest patches on sandur. They were: Leucobryum glaucum Hedw., Pleurozium schreberi (Willd. ex Brid.) Mitt.), Dicranum scoparium Hedw. and Taxus baccata L. except for Pyrola rotundifolia L. present in the area previously cultivated in agriculture.

On the moraine in the ecotone zone of forest patches significantly more plant species (177 species) were found as compared to sandur areas (95 plant species) (Table A1). Of all the plant species, forest and scrub flora (92 species) dominated and there were also meadow and grassland plants ( 77 species). The diversity of the number of species at 20 research sites was, in the case of forest grasslands, not large, contrary to meadow grassland flora. The plant species from the remaining sociological and ecological groups were less common (ruderal - 29; marsh - 15). Flora belonging to the remaining groups occurred mainly in the post-cultivated moraine areas (marsh species - 100\%, ruderal - 86\%, meadow - 65\%).

The identified plant species belonged to 13 phytosociological classes (Fig. 2), with a predominance of forest habitats, i.e. Vacccinio-Piceetea - coniferous forests, QuercoFagetea - eutrophic deciduous forests and Epilobietea angustifolii - semi-natural field communities (from 33 to 55 species) and meadow habitats - the Molinio-Arrhenatheretea class (from 26 to 50 species).

Table 4 and Figure 3 show a statistical description of the results of the studies and variance analysis for synanthropisation and environmental indices (Trophy: soil nitrogen content indicator, $\mathrm{pH}$ : the value of the acidity index in the soil, Valorisation: the value of the natural valorisation index).

The synathropisation index took on larger values in an area previously used as an arable field in an afforested area, while the terrain had no influence on the value of the index calculated. The larger number of alien species such as Lupinus polyphyllus L., Myosotis arvensis (L.) Hill., Sonchus asper (L.) Hill. was responsible for the quantity of this parameter.

Error bars represente of the variability of data and used on graphs to indicate the error or uncertainty in a reported measurement. In our studies, the amount of variability in the data corresponds to field studies. The largest index values (4.3 and 3.4) characterising plant habitat properties (trophy, soil $\mathrm{pH}$ ) occurred in an area used earlier as an arable field within moraine. The natural valorisation index for this research area was smaller than the previously wooded area and situated within sandur. In this area, there were numerous species with high valorisation values: Hypogymnia psysodes (L.) Nyl., Hypocenomyce scalaris (Ach. ex Lilj.) M. Choisy, Taxus baccata L. From the indices analysed (synanthropization $\mathrm{W}_{\mathrm{s}}$, naturalness $\mathrm{W}_{\mathrm{n}}$ and flora anthropophytization $\mathrm{W}_{\mathrm{a}}$ ) only the synanthropization index turned out to be a parameter sensitive to land use, which indicates its usability at the assessment of transformations of the small areas of woodland studied. 


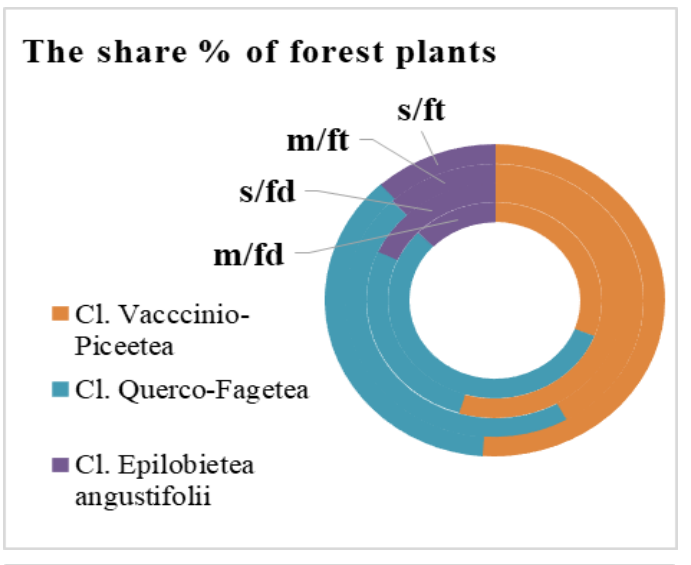

The share \% of ruderal and nitrophilous plants

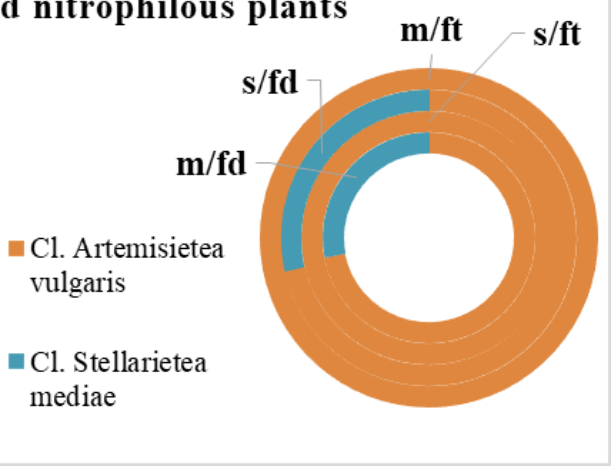

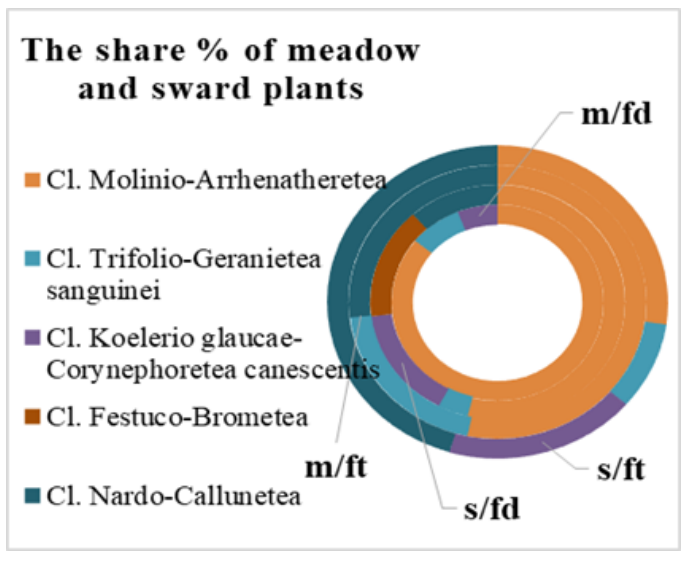

The share \% of marsh plants

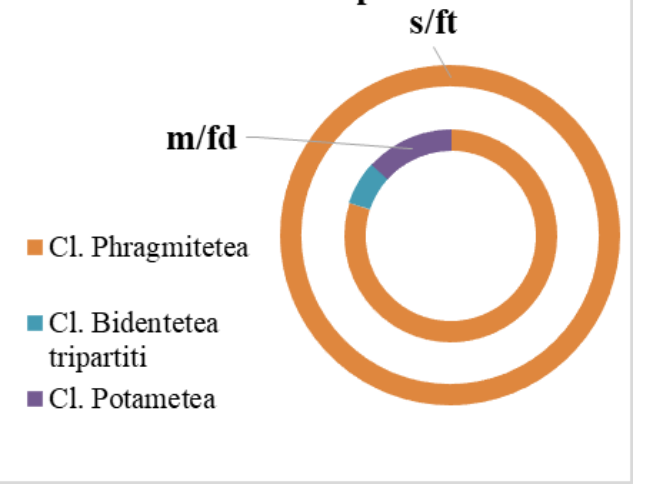

Figure 2. The share of plant species belonging to phytosociological classes identified on the studied forest patches. s: object is located on the sandur, m: object is located on the moraine, $f d$ : object is located in the area previously used for agriculture, ft: object is located in a previously forested area

Table 4. Synanthropization index values on the studied forest patches

\begin{tabular}{c|c|c|c|c|c}
\hline $\begin{array}{c}\text { Geomorphological } \\
\text { unit }\end{array}$ & Prior land use & Medium & $\begin{array}{c}\text { Standard } \\
\text { error }\end{array}$ & $\mathbf{- 9 5 . 0 0 \%}$ & $\mathbf{+ 9 5 . 0 0 \%}$ \\
\hline $\mathrm{m}$ & $\mathrm{fd}$ & $230^{\mathrm{b}}$ & \pm 48 & 129 & 331 \\
$\mathrm{~m}$ & $\mathrm{ft}$ & $71^{\mathrm{a}}$ & \pm 10 & 50 & 91 \\
$\mathrm{~s}$ & $\mathrm{fd}$ & $178^{\mathrm{b}}$ & \pm 23 & 129 & 227 \\
$\mathrm{~s}$ & $\mathrm{ft}$ & $39^{\mathrm{a}}$ & \pm 6 & 26 & 52 \\
\hline
\end{tabular}

a, b: homogeneous groups, $\mathrm{N}$ : 20 research areas, s: object is located on the sandur, m: object is located on the moraine, fd: object is located in the area previously used for agriculture, $\mathrm{ft}$ : object is located in a previously forested area

The species occurring in the post-cultivated areas of moraine are characteristic of lowpH habitats, for example Juncus effusus L., Maianthemum bifolium (L.) F. W. Schmidt, Oxalis acetosella L. (acidification indicators). The species occurring in post-cultivated moraine terrain need habitats with a soil of larger trophic values, including: Aegopodium podagraria L., Galium aparine L., Urtica dioica L. 
Environmental index

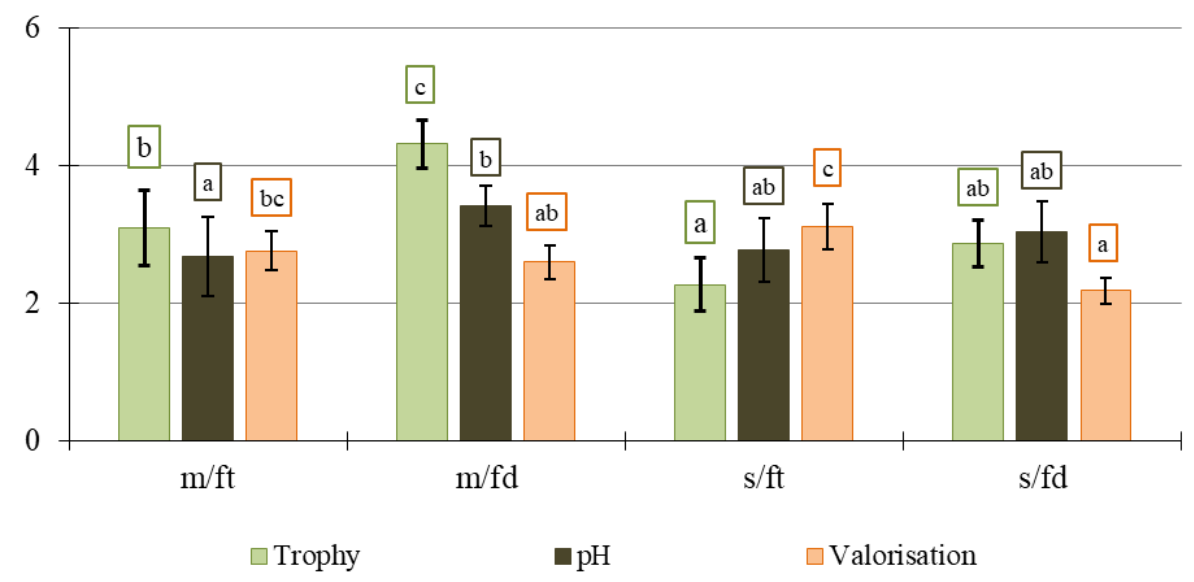

Figure 3. Values of environmental indexes on studied areas (Mean \pm standard error (SE)), Means with the same uppercase letter are not significantly different ( $p>0.05), a, b, c$ : homogeneous groups, $n: 20$ research areas, $s$ : object is located on the sandur, $m$ : object is located on the moraine, fd: object is located in the area previously used for agriculture, ft: object is located in a previously forested area, Trophy: soil nitrogen content indicator, $\mathrm{pH}$ : the value of the acidity index in the soil, Valorisation: the value of the natural valorisation index

The statistical analysis showed (Fig. 4), that the largest number of plant species occurred within moraine in an area previously used as an arable field which, at the same time, resulted in the largest number of species, including neutral species, i.e. poorly spreading and occurring only in habitats appropriate for them. These were, among others: Carex elata All., Equisetum palustre L., Scirpus sylvaticus L.

\section{Number of species}

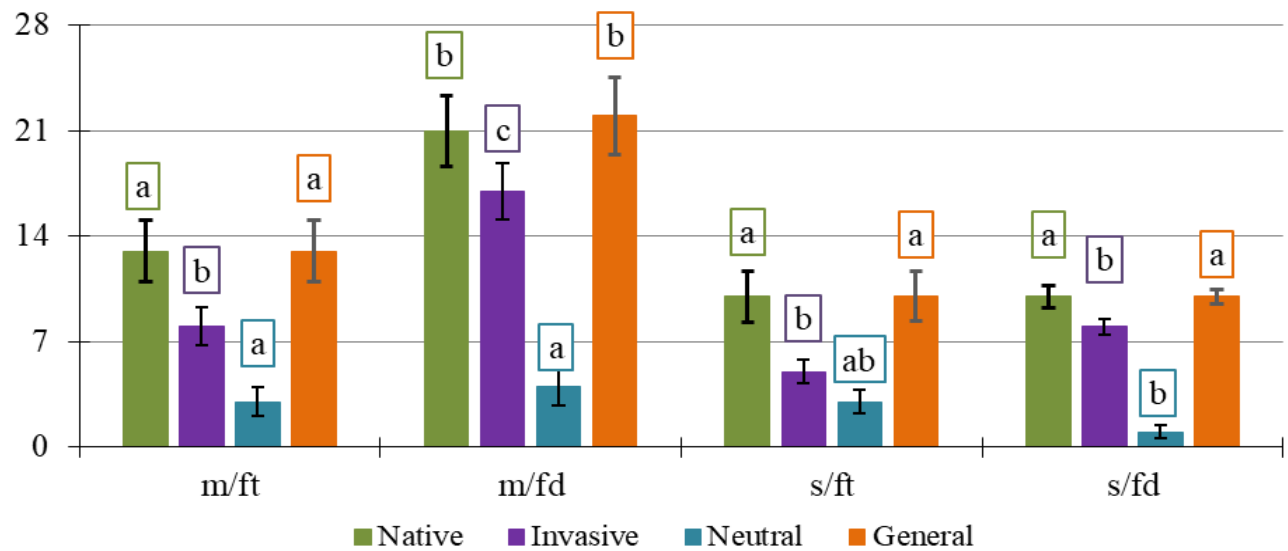

Figure 4. The number of native, invasive and neutral species on the studied forest patches. (Mean \pm standard error (SE)), Means with the same uppercase letter are not significantly different ( $p>0.05$ ), $a, b, c$ : homogeneous groups, $n$ : 20 research areas, $s$ : object is located on the sandur, $m$ : object is located on the moraine, fd: object is located in the area previously used for agriculture, ft: object is located in a previously forested area, Native: very poorly spreading species, Invasive: invasive rapidly spreading species, Neutral: neutral species, i.e. poorly spreading, General: the total number of species 
Error bars represente of the variability of the number of species. In our studies, the amount of variability in this data corresponds to botanical studies. The fewest number of species was recorded in an area previously afforested within sandur. The species were under mutual influence, which mainly referred to the impingement of invasive species. In the assessment of transformations, the ecological indices including the trophy, soil $\mathrm{pH}$ and valorisation indices showed differentiation as regards to the varied terrain and land use.

It was established that there was a significance linear correlation between the plant habitat trophy and soil $\mathrm{pH}$ indices, and the total number of species, including native, invasive and neutral (Table 5). The value of the natural valorisation index was negatively correlated with the number of invasive species. The presented values indicate strong $(\mathrm{r}=0.60)$, moderate $(\mathrm{r}=0.42$ or 0.56$)$, and weak $(\mathrm{r}=-0.24$ or 0.25 or 0.28 or 0.34$)$ correlation between the evaluated parameters, but it is clear evidence that there is a correlation between the soil parameters first of all the soil $\mathrm{pH}$ and the species diversity because all species have an optimum range in terms of all environmental parameters. Additionally, it is a natural phenomenon that the occurrence of the invasive species is more frequent under non-optimum conditions such as too high or low $\mathrm{pH}$.

Table 5. The linear correlation coefficient between the analyzed indexes, and the number of species in the studied forest patches

\begin{tabular}{c|cccc|cccc}
\hline \multirow{2}{*}{ Parameter } & \multicolumn{4}{|c|}{ Index } & \multicolumn{4}{c}{ Number } \\
\cline { 2 - 9 } & St & Trophy & pH & Valorisation & Native & Invasive & Neutral & $\boldsymbol{\Sigma}$ \\
\hline Index trophy & $0.25^{*}$ & 1.00 & $0.42^{*}$ & - & $0.60^{*}$ & $0.56^{*}$ & $0.34^{*}$ & $0.60^{*}$ \\
Index pH & - & $0.42^{*}$ & 1.00 & - & - & $0.28^{*}$ & - & - \\
Index valorisation & - & - & - & 1.00 & - & $-0.24 *$ & - & - \\
\hline
\end{tabular}

Level of significance, $*<0.05$. St: synanthropization index, Trophy: soil nitrogen content indicator, $\mathrm{pH}$ : the value of the acidity index in the soil, Valorisation: the value of the natural valorisation index, Native: very poorly spreading species, Invasive: invasive rapidly spreading species, Neutral: neutral species, i.e. poorly spreading

The species classified as invasive, i.e. characterized by rapid spreading and colonizing all available habitats, and also characterized by low valorisation number values are Artemisia vulgaris L., Calamagrostis epigejos (L.) Roth., Elymus repens (L.) Gould.

\section{Discussion}

Currently available knowledge on the ecosystem services of forest patches (Takkis et al., 2018), is still lacking in comparison with that on large forest areas (Gamfeldt et al., 2013; Biber et al., 2015). Therefore, it is vital to extend the knowledge on the role of forest patches in maintaining, among others, biological diversity in a landscape under heavy anthropogenic pressure, such as agricultural lands. As a result of economic and social transformations, the areas under study are characterised by the emergence of large areas of fallow lands, particularly on sandur areas (Majewski and Marszałek, 2020), and the only way in which these poor soils (complex 6 and 7 of agricultural use) could be developed and used was afforestation (Schmidt, 2015). In the analysed area, the predominant were slightly loamy sand (85\% in sandur and $70 \%$ in moraine). In individual forest patches there were also sand and clay, respectively. 
The complexity of the landscape composition (e.g. kame, esker, valley, ravine) due to glacier retreat determines the occurrence of small elements of landscape (Pieńkowski et al., 2019), including forest patches. In the analysed moraine areas, which show greater diversity in terms of land relief and, consequently, are richer in other natural ecosystems, there were almost 2 times more plant species in comparison with the sandur areas. The diversity of herbaceous flora resulted from a low density of the shrub layer (from 0 to 40\%). According to Hladnik et al. (2020), the limit values preventing the rejuvenation of tree stand and development of forest floor vegetation is $60 \%$ area covered with shrubs. In the analysed areas, the most diverse tree stand, and forest floor vegetation were found on the previously afforested moraine area. However, the richest layer of moss and forest floor vegetation was found on previously afforested sandur areas.

The previous use of forest patches as agricultural lands may have a negative effect on the quality of the tree stand as well as plants of the forest floor vegetation. The studies by Buffa et al. (2018) and Jelonek et al. (2019) showed a decrease in wood biomass production and flora diversity with the increasing age of forest patches. Similar results were obtained by Foli et al. (2015) and Van Dijk (2018), who reported changes in flora composition and deterioration of habitats due to the change of the form of land use. This is confirmed by own studies which indicate fewer plant species in the areas which previously had been used for agricultural purposes in comparison with previously afforested areas. The origin of forest patches determined the rate of flora succession. The flora changes in the areas previously used for agricultural purposes concerned $30 \%$ of species, whereas in the afforested areas the changes were non-substantial. Skrajna (2020) showed that with the high number of typically forest species in the extreme parts, the diversity of the whole ecotone zone increases. The share of coniferous and deciduous species (respectively, class Vaccinio-Piceetea and Querco-Fagetea) in the analysed areas was $25 \%$.

The studies by Dzwonko (2015) showed that the previously afforested areas were characterised by a greater flora diversity of ecotone zones, particularly of forest species a fact explained by Meszaros (2012) by their fast rate of vegetative propagation. The following forest species, among others, were observed in the analysed areas: Asarum europaeum L., Convallaria majalis L., Oxalis acetosella L., Hedera helix L., Viola reichenbachiana Jordan ex Bor., Poa nemoralis L., Luzula pilosa (L.) Willd. or Vaccinium myrtillus L. In the forest patches which were previously used for agricultural purposes, ruderal species were expansive, e.g. Cirsium arvense (L.) Scop.), Rubus idaeus L. and Urtica dioica L.

Additionally, floristic diversity depends on the tree stand. According to Gamfeldt et al. (2013) and Lõhmus et al. (2014), diversity is hindered by a high share of coniferous trees, particularly in the borderline zone - in the analysed area, Pinus sylvestris L. showed the highest share among other forest-forming species. With the presence of Pinus sylvestris, the forest floor vegetation was dominated by Deschampsia flexuosa L. (forest species forming aggregations). With the presence of deciduous species (e.g. Betula pendula Roth., Fagus sylvatica L., Populus tremula L., Quercus robur L.), ruderal species were numerous (e.g. Aegopodium podagraria L., Rubus idaeus L., Geum urbanum L.). The studies by Kryszak et al. (2014) showed high occurrence of Deschampsia flexuosa L. and Poa nemoralis L. on sandur areas. The preference of these grass species i.e., dry and slightly acidic habitats (Plue et al., 2020), made the analysed forest patches an unsuitable habitat for these plants. 
In Europe, the characteristics of a given environment, the so-called filtering, consists of the analysis of the preference of a given species in terms of a specified factor (Silvertown et al., 2006; Bartelheimer and Poschlod, 2015). The study on the transformation of the vascular flora of forest, after a period of 20 years, showed high values of the synantrophization index $(>50 \%)$ and a low degree of flora naturalness (24.4\%) (Ziaja and Wójcik, 2015). The values of the synantrophization index in pine stand ranged from 0.39 to 0.52 (Stepanovich, 2019). In the present study, the obtained values of syntantrophization index $(E q .1)$ were 3.8 times higher in comparison to afforested areas, and 1.4 times higher within moraine areas.

The studies by Stepanovich (2019) on the occurrence of invasive species in pine forests showed 16 very invasive species - capable of inducing a radical transformation of native phytocenoses and the creation of own communities (e.g. Robinia pseudoacacia L.), 14 species resilient to unfavourable environmental conditions (e.g. Impatiens parviflora DC.), and 2 species quickly reacting to substrate disturbances (np. Conyza canadensis (L.) Cronquist). In the analysed area, the highest number of invasive species (according to synanthropodynamic classification) was found in forest patches previously used for agricultural purposes.

The studies conducted by Skrajna (2020) indicated greater differences in the values of Ellenberg ecological indices with respect to nitrogen content and acidity of the habitat between forest patches located in areas previously used for agricultural purposes and those located in previously afforested areas. The values of environmental valorisation index of forest ecotone zone ranged from moderately high to low (Gamrat et al., 2019). The said values determined for the analysed areas were even lower.

The effect of forest patches on the flow of ecosystemic services, including preservation of biodiversity (Takkes et al., 2018; Bergès and Dupouey, 2020), is critical for agricultural landscape. The objects with sustainable ecological continuity, such as forest patches located in areas which have been afforested for a long time, are considered particularly valuable for nature protection (Nordén et al., 2014).

\section{Conclusions}

The applied method of phytoindication with Ellenberg's and Oświt's indices made it possible to assess differences in the research areas. Land use (agricultural and forest use) was found to be responsible for a positive interrelationship between trophy and synanthropisation indices, no matter the type of geomorphological unit. On the basis of species composition in the ecotone zone of small areas of woodland in the research areas it was established that within the moraine area previously used agriculturally (the most species of trees, shrubs, green vegetation, mosses and lichens) there was a cumulation of species due to the habitat diversity of ecological niches resulting from the terrain, the amount of mineral nutrients in the soil and the large number of particularly native and neutral species in the gene pool. The ecotone zones in sandur areas of forest patches offer better conditions for the preservation of protected species owing to the smaller variability in habitat parameters. In view of the observed climate change, it is now important to properly manage the drought-affected fields. Monitoring of biodiversity in sandur areas can help in choosing the right direction in maintaining the phytodiversity of the agricultural landscape. 


\section{REFERENCES}

[1] Bartelheimer, M., Poschlod, P. (2015): Functional characterizations of Ellenberg indicator values - a review on ecophysiological determinants. - Functional Ecology 30(4): 506-516.

[2] Batary, P., Baldi, A., Kleijn, D., Tscharntke, T. (2011): Landscape moderated biodiversity effects of agri environmental management: a meta analysis. - Proceedings of the Royal Society B: Biological Sciences 278: 1894-1902.

[3] Baude, M., Meyer, B. C., Schindewolf, M. (2019): Land use change in an agricultural landscape causing degradation of soil based ecosystem services. - Science of the Total Environment 659: 1526-1536.

[4] Bergès, L., Dupouey, J.-L. (2020): Historical ecology and ancient forests: progress, conservation issues and scientific prospects, with some examples from the French case. Journal of Vegetation Science 32(1): e12846.

[5] Biber, P., Borges, J. G., Moshammer, R., Barreiro, S., Botequim, B., Brodrechtová, Y., Brukas, V., Chirici, G., Cordero-Debets, R., Corrigan, E., Eriksson, L. O., Favero, M., Galev, E., Garcia-Gonzalo, J., Hengeveld, G., Kavaliauskas, M., Marchetti, M., Marques, S., Mozgeris, G., Navrátil, R., Nieuwenhuis, M., Orazio, C., Paligorov, I., Pettenella, D., Sedmák, R., Smreček, R., Stanislovaitis, A., Tomé, M., Trubins, R., Tuček, J., Vizzarri, M., Wallin, I., Pretzsch, H., Sallnäs, O. (2015): How sensitive are ecosystem services in European forest landscapes to silvicultural treatment? - Forests 6: 1666-1695.

[6] Buffa, G., Del Vecchio, S., Fantinato, E., Milano, V. (2018): Local versus landscape-scale effects of anthropogenic land-use on forest species richness. - Acta Oecologica 86: 49-56.

[7] Chabrerie, O., Jamoneau, A., Gallet-Moron, E., Decocq, G. (2013): Maturation of forest edges is constrained by neigh-bouring agricultural land management. - Journal of Vegetation Science 24: 58-69.

[8] Chazdon, R. L., Brancalion, P. H. S., Laestadius, L., Bennett-Curry, A., Buckingham, K., Kumar, C., Moll-Rocek, J., Guimara es Vieira, I. C., Wilson, S. J. (2016): When is a forest a forest? Forest concepts and definitions in the era of forest and landscape restoration. Ambio 45(5): 538-550.

[9] Chmiel, J. (1993): The flora of vascular plants in the eastern part of the Gniezno Lake District and its anthropogenic transformations in the 19th and 20th centuries. Part II. Plant distribution. - University of Adam Mickiewicz in Poznań, Poznań, 212p. (in Polish).

[10] Decocq, G., Andrieu, E., Brunet, J., Chabrerie, O., De Frenne, P., De Smedt, P., Deconchat, M., Diekmann, M., Ehrmann, S., Giffard, B., Gorriz, Mifsud, E., Hansen, K., Hermy, M., Kolb, A., Lenoir, J., Liira, J., Moldan, F., Prokofieva, I., Rosenqvist, L., Varela, E., Valdés, A., Verheyen, K., Wulf, M. (2016): Ecosystem services from small forest patches in agricultural landscapes. - Current Forestry Reports 2(1): 30-44.

[11] Dzwonko, J. (2008): Guide to phytosociological's research. - Publisher Sorus, Poznań Kraków, 304p. (in Polish).

[12] Dzwonko, Z. (2015): Herb layer plants as indicators of woodland origin and changes. Studia i Materiały CEPL w Rogowie 42(1): 27-38.

[13] Ellenberg, H., Weber, H. E., Düll, R., Wirth, V., Werner, W., Paulissen, D. (1991): Central European plant index values. - Scripta Geobotanica, Göttingen, 248p. (in German).

[14] Esseen, P., Hedström, A., Ringvall, A., Harper, K. A., Christensen, P., Svensson, J. (2016): Factors driving structure of natural and anthropogenic forest edges from temperate to boreal ecosystems. - Journal of Vegetation Science 27: 482-492.

[15] Foli, S., Reed, J., Clendenning, J., Petrokofsky, G., Padoch, C., Sunderland, T. C. (2015): To what extent does the presence of forests and trees contribute to food production in humid and dry forest landscapes? - Environmental Evidence 3(1): 1-8.

[16] Forrest, J. R., Thorp, R. W., Kremen, C., Williams, N. M. (2015): Contrasting patterns in species and functional-trait diversity of bees in an agricultural landscape. - Journal of Applied Ecology 52(3): 706-715. 
[17] Gamfeldt, L., Snäll, T., Bagchi, R., Jonsson, M., Gustafsson, L., Kjellander, P., Ruiz-Jaen, M. C., Fröberg, M., Stendahl, J., Philipson, C. D., Mikusiński, G., Andersson, E., Westerlund, B., Andrén, H., Moberg, F., Moen, J., Bengtsson, J. (2013): Higher levels of multiple ecosystem services are found in forests with more tree species. - Nature Communication 4: 1340.

[18] Gamrat, R., Gałczyńska, M. (2014): Influence of the forest ecotone structure on the phytodiversity. - Sylwan 158(1): 34-40. (in Polish).

[19] Gamrat, R., Gałczyńska, M., Sotek, Z., Stasińska, M. (2019): The impact of neighbouring ecosystems on species composition in the ecotone of small forest plots: case study in Choszczno Forest Inspectorate in NW Poland. - Russian Journal of Ecology 50: 465-473.

[20] Haddad, N. M., Brudvig, L. A., Clober, T. J., Davies, K. F., Gonzalez, A., Holt, R. D., Lovejoy, T. E., Sexton, J. O., Austin, M. P., Collins, C. D., Cook, W. M., Damschen, E. I., Ewers, R. M., Foster, B. L., Jenkins, C. N., King, A. J., Laurance, W. F., Levey, D. J., Margules, C. R., Melbourne, B. A., Nicholls, A. O., Orrock, J. L., Song, D.-X., Townshend, J. R. (2015): Habitat fragmentation and its lasting impact on Earth's ecosystems. - Science of Advanced Materials 1(2): e1500052.

[21] Hladnik, D., Kobler, A., Pirnat, J. (2020): Evaluation of forest edge structure and stability in peri-urban forests. - Forests 11(3): 338.

[22] Jamoneau, A., Chabrerie, O., Closset-Kopp, D., Decocq, G. (2012): Fragmentation alters beta-diversity patterns of habitat specialists within forest metacommunities. - Ecography 35: 124-33.

[23] Jelonek, T., Arasimowicz-Jelonek, M., Gzyl, J., Tomczak, A., Łakomy, P., Grzywiński, W., Remlein, A., Klimek, K., Kopaczyk, J., Jaszczak, R., Kuźmiński, R. (2019): Influence of former farmland on the characteristics and properties of scots pine (Pinus sylvestris L.) tree tissue. - Bioresources 14(2): 3247-3265.

[24] Jia, H. R., Chen, Y., Yuan, Z. L., Ye, Y. Z., Huang, Q. C. (2015): Effects of environmental and spatial het-erogeneity on tree community assembly in Baotianman National Nature Reserve, Henan, China. - Polish Journal of Ecology 63(2): 175-183.

[25] Jia, H. R., Chen, Y., Wang, X. Y., Li, P. K., Yuan, Z. L., Ye, Y. Z. (2019): The relationships among topographically-driven habitats, dominant species and vertical layers in temperate forest in China. - Russian Journal of Ecology 50(2): 172-186.

[26] JL (2014): Regulation of the Minister of the Environment on the Protection of Plant Species. - Journal of Laws 2014 no. 0, item 1409.

[27] Kryszak, A., Maćkowiak, K., Klarzyńska, A., Szczepańska, N., Kryszak, J. (2014): Fluctuation in grasses cover during the growing season in some types of forests. Grassland Science in Poland 17: 61-71. (in Polish).

[28] Liu, Z., Jia, G., Yu, X. (2020): Variation of water uptake in degradation agroforestry shelterbelts on the North China Plain. - Agriculture, Ecosystems and Environment 287: 106697.

[29] Lõhmus, K., Paal, T., Liira, J. (2014): Long-term colonization ecology of forest-dwelling species in a fragmented rural landscape - dispersal versus establishment. - Ecology and Evolution 4: 3113-3126.

[30] Majewski, M., Marszałek, L. (2020): Forest cover changes over historical times in the area of Lake Jasień (northern Poland) recorded in slope sediments and archival maps - a case study. - Proceedings of the Estonian Academy of Sciences 69(1): 43-52.

[31] Matuszkiewicz, W. (2017): Guide to the identification of plant communities in Poland. State Scientific Publishers, 3th edition, Warsaw, 540p. (in Polish).

[32] Meszaros, I. (2012): Community pattern in a small scale forest ecotone. - In: Teller, A., Mathy, P., Jeffers, J. N. R. (eds.) Responses of forest ecosystems to environmental changes. Springer, Dodrecht, pp. 906-909.

[33] Nordén, B., Dahlberg, A., Brandrud, T. E., Fritz, Ö., Ejrnaes, R., Ovaskainen, O. (2014): Effects of ecological continuity on species richness and composition in forests and woodlands: a review. - Écoscience 21(1): 34-45. 
[34] Oświt, J. (2000): The method of valuation of natural wetlands and the results of its application on selected objects. - IMUZ Press 35, Falenty: 36. (in Polish).

[35] Pieńkowski, P., Podlasiński, M., Szpigiel, M. (2019): Reasons for the occurence of small forest patches within post-glacial areas used for agriculture in northern Poland. - Applied Ecology and Environmental Research 17(5): 11995-12011.

[36] Plue, J., Cousins, S. A. O., De Pauw, K., Diekmann, M., Hagenblad, J., Helsen, K., Hermy M., Liira, J., Orczewska, A., Vanneste, T., Wulf, M., De Frenne, P. (2020): Biological flora of the British Isles: Poa nemoralis. - Journal of Ecology 108(4): 1750-1774.

[37] Proesmans, W., Bonte, D., Smagghe, G., Meeus, I., Decocq, G., Spicher, F., Kolb, A., Lemke, I., Diekmann, M., Bruun, H. H., Wulf, M., Van Den Berge, S., Verheyen, K. (2019): Small forest patches as pollinator habitat: oases in an agricultural desert? Landscape Ecology 34: 487-501.

[38] Schmidt, C. (2015): The forests in Germany. - Federal Ministry of Food and Agriculture, $56 \mathrm{p}$.

[39] Silvertown, J., Dodd, M., Gowing, D., Lawson, C., McConway, K. (2006): Phylogeny and the hierarchical organization of plant diversity. - Ecology 87: 39-49.

[40] Skrajna, T. (2020): Impact of agriculture intensification on the floristic diversity of the forest-field ecotone. - Polish Journal of Ecology 68(1): 47-66.

[41] Stepanovich, I. M. (2019): The invasive potential of synanthropic components of pine forests in Belarus. - Trudy 1(2): 90-98. (in Russian).

[42] Takkis, K., Kull, T., Hallikma, T., Jaksi, P., Kaljund, K., Kauer, K., Kull, T., Kurina, O., Külvik, M., Lanno, K., Liira, J., Melts, I., Pehlak, H., Raet, J., Sammet, K., Sepp, K., Väli, Ü., Laanisto, L. (2018): Drivers of species richness and community integrity of small forest patches in an agricultural landscape. - Journal of Vegetation Science 26(6): 978-988.

[43] Van Dijk, J. (2018): Biodiversity and nature. The Netherlands and the Dutch. - World Regional Geography Book Series, pp. 81-104.

[44] Wysocki, C., Sikorski, P. (2002): Phytosociology applied. - SGGW Press, Warsaw, 449p. (in Polish).

[45] Ziaja, M., Wójcik, T. (2015): Changes in vascular flora of the Rzeszow reservoir after 20 years (SE Poland). - Polish Journal of Environmental Studies 24(4): 1845-1854. 


\section{APPENDIX}

Table A1. Phytosociological classification of the founded plant species

\begin{tabular}{|c|c|c|c|c|}
\hline No. & 1 & 2 & 3 & 4 \\
\hline Geomorphological unit & Moraine & Sandur & Moraine & Sandur \\
\hline Prior land use & Field & Field & Forest & Forest \\
\hline Cover a [\% min., max., av.] & $0,100,16$ & 100 & $10,100,67$ & $30,100,84$ \\
\hline Cover b [\% min., max., av.] & $0,20,4$ & $0,40,14$ & $0,40,13$ & $10,30,17$ \\
\hline Cover c [\% min., max., av.] & $10,100,41$ & 100 & $20,100,41$ & 100 \\
\hline Cover d [\% min., max., av.] & $1,1,1$ & $1,1,1$ & $0,10,3$ & $0,10,6$ \\
\hline Constancy S-Coefficient D for 10 phytosociological releve's & S-D & S-D & S-D & S-D \\
\hline \multicolumn{5}{|l|}{ I. Cl. Vaccinio-Piceetea, O. Cladonio-Vaccinietalia } \\
\hline Pinus sylvestris a & $\mathrm{I}-88$ & II- 285 & II -230 & II- 248 \\
\hline Vaccinium myrtillus c & . & $\mathrm{I}-38$ & III-270 & II-53 \\
\hline Pleurozium schreberi $\mathrm{d}$ & $\mathrm{I}-<1$ & . & $\mathrm{I}-10$ & $\mathrm{I}-20$ \\
\hline \multicolumn{5}{|l|}{ All. Dicrano-Pinion, Ass. Leucobryo-Pinetum } \\
\hline Deschampsia flexuosa c & $\mathrm{I}-43$ & V-436 & II -245 & IV-615 \\
\hline Sorbus aucuparia b & $\mathrm{I}-<1$ & III-19 & IV-71 & $\mathrm{V}-12$ \\
\hline Lepraria incana $\mathrm{d}$ & . & . & $\mathrm{I}-20$ & II-38 \\
\hline Leucobryum glaucum $\mathrm{d}$ & . & . & . & II-10 \\
\hline Rumex acetosella $\mathrm{c}$ & $\mathrm{I}-<1$ & III-1 & . & $\mathrm{I}-1$ \\
\hline \multicolumn{5}{|l|}{ O. Vaccinio-Piceetalia, All. Piceion abietis } \\
\hline Agrostis capillaris c & . & III-278 & $\mathrm{I}-18$ & III-11 \\
\hline Maianthemum bifolium $\mathrm{c}$ & $\mathrm{I}-0.1$ & . & $\mathrm{I}-90$ & . \\
\hline Dryopteris filix-mas c & II-63 & III-1 & III-36 & II-36 \\
\hline Betula pendula a & $\mathrm{I}-18$ & $\mathrm{I}-38$ & IV-133 & III-88 \\
\hline Populus tremula a & $\mathrm{I}-80$ & $\mathrm{I}-18$ & $\mathrm{I}-75$ & . \\
\hline Picea abies a & $\mathrm{I}-88$ & . & $\mathrm{I}-63$ & $\mathrm{I}-10$ \\
\hline Betula pubescens $\mathrm{b}$ & . & . & . & $\mathrm{I}-75$ \\
\hline Veronica officinalis c & $\mathrm{I}-<1$ & II-53 & $\mathrm{I}-18$ & . \\
\hline Pteridium aquilinum c & . & $\mathrm{I}-<1$ & $\mathrm{I}-<1$ & $\mathrm{I}-35$ \\
\hline Holcus mollis c & $\mathrm{I}-<1$ & II-15 & . & $\mathrm{I}-<1$ \\
\hline \multicolumn{5}{|l|}{ II. Cl. Querco-Fagetea } \\
\hline Quercus robur a & . & . & III-136 & III-1 \\
\hline Alnus glutinosa a & . & $\mathrm{I}-1$ & $\mathrm{I}-150$ & $\mathrm{I}-35$ \\
\hline Impatiens noli-tangere $\mathrm{c}$ & . & $\mathrm{I}-18$ & . & II-76 \\
\hline Oxalis acetosella $\mathrm{c}$ & $\mathrm{I}-75$ & . & II-93 & . \\
\hline Milium effusum c & $\mathrm{I}-<1$ & . & $\mathrm{I}-73$ & II-11 \\
\hline Fagus sylvatica a & $\mathrm{I}-18$ & . & II-73 & . \\
\hline Scirpus sylvaticus c & $\mathrm{I}-40$ & . & . & . \\
\hline Hypogymnia physodes $\mathrm{d}$ & . & . & . & II-38 \\
\hline Quercus robur b & $\mathrm{I}-23$ & III-1 & . & . \\
\hline Carex sylvatica $\mathrm{c}$ & . & . & $\mathrm{I}-18$ & $\mathrm{I}-<1$ \\
\hline Acer platanoides a & . & $\mathrm{I}-1$ & $\mathrm{I}-18$ & . \\
\hline Rubus caesius b & . & . & II-18 & $\mathrm{I}-18$ \\
\hline Geum rivale c & $\mathrm{I}-18$ & . & $\mathrm{I}-<1$ & $\mathrm{I}-<1$ \\
\hline Hedera helix $\mathrm{c}$ & . & . & $\mathrm{I}-18$ & . \\
\hline \multicolumn{5}{|l|}{ III. Cl. Epilobietea angustifolii } \\
\hline Rubus idaeus b & $\mathrm{I}-<1$ & IV-1 & III-170 & $\mathrm{V}-257$ \\
\hline Fragaria vesca $\mathrm{c}$ & $\mathrm{I}-<1$ & $\mathrm{I}-<1$ & $\mathrm{I}-55$ & $\mathrm{I}-<1$ \\
\hline Calamagrostis epigejos $\mathrm{c}$ & . & II-37 & $\mathrm{I}-1$ & $\mathrm{I}-1$ \\
\hline Sambucus nigra $\mathrm{b}$ & $\mathrm{I}-18$ & $\mathrm{I}-<1$ & $\mathrm{I}-<1$ & $\mathrm{I}-<1$ \\
\hline
\end{tabular}




\begin{tabular}{|c|c|c|c|c|}
\hline \multicolumn{5}{|l|}{ IV. Cl. Molinio-Arrhenatheretea } \\
\hline Trifolium pratense $\mathrm{c}$ & II-98 & . & . & . \\
\hline Equisetum palustre $\mathrm{c}$ & $\mathrm{I}-88$ & . & . & . \\
\hline Lotus corniculatus c & II-53 & . & . & . \\
\hline Juncus effusus c & II-38 & . & $\mathrm{I}-1$ & . \\
\hline Deschampsia caespitosa $\mathrm{c}$ & II-56 & . & $\mathrm{I}-<1$ & . \\
\hline Caltha palustris $\mathrm{c}$ & $\mathrm{I}-<1$ & . & $\mathrm{I}-35$ & . \\
\hline Ranunculus acris c & III-1 & . & $\mathrm{I}-<1$ & . \\
\hline Cirsium oleraceum $\mathrm{c}$ & $\mathrm{I}-35$ & . & . & . \\
\hline Agropyron repens $\mathrm{c}$ & $\mathrm{I}-23$ & $\mathrm{I}-<1$ & . & . \\
\hline Daucus carota $\mathrm{c}$ & II-18 & . & . & . \\
\hline Heracleum sphondylium c & II-18 & . & . & . \\
\hline Trifolium dubium $\mathrm{c}$ & II-18 & . & . & . \\
\hline Stellaria graminea $\mathrm{c}$ & $\mathrm{I}-5$ & II-1 & . & $\mathrm{I}-<1$ \\
\hline Knautia arvensis $\mathrm{c}$ & $\mathrm{I}-<1$ & II-1 & $\mathrm{I}-<1$ & . \\
\hline Dactylis glomerata c & II-1 & $\mathrm{I}-<1$ & $\mathrm{I}-<1$ & . \\
\hline \multicolumn{5}{|l|}{ V. Cl. Artemisietea vulgaris } \\
\hline Urtica dioica $\mathrm{c}$ & III-195 & $\mathrm{I}-<1$ & I-63 & . \\
\hline Aegopodium podagraria $\mathrm{c}$ & $\mathrm{I}-63$ & . & II-88 & . \\
\hline Geum urbanum c & II-18 & . & III-88 & . \\
\hline Galium aparine c & III-63 & $\mathrm{I}-<1$ & $\mathrm{I}-18$ & . \\
\hline Chelidonium majus $\mathrm{c}$ & . & . & I-38 & . \\
\hline Glechoma hederacea c & $\mathrm{I}-<1$ & . & $\mathrm{I}-38$ & . \\
\hline Geranium robertianum c & $\mathrm{I}-<1$ & . & II-35 & $\mathrm{I}-<1$ \\
\hline Rumex obtusifolius c & $\mathrm{I}-35$ & . & . & . \\
\hline Artemisia vulgaris $\mathrm{c}$ & II-23 & . & . & . \\
\hline Epilobium hirsutum $\mathrm{c}$ & II-5 & . & $\mathrm{I}-<1$ & . \\
\hline Melilotus officinalis c & $\mathrm{I}-18$ & . & . & . \\
\hline \multicolumn{5}{|l|}{ VI. Cl. Phragmitetea } \\
\hline Phragmites australis c & $\mathrm{I}-61$ & . & . & . \\
\hline Carex elata c & $\mathrm{I}-31$ & . & . & $\mathrm{I}-<1$ \\
\hline Typha latifolia $\mathrm{c}$ & $\mathrm{I}-43$ & . & . & . \\
\hline Salix cinerea $\mathrm{b}$ & $\mathrm{I}-38$ & . & . & . \\
\hline Carex disticha $\mathrm{c}$ & $\mathrm{I}-38$ & . & . & . \\
\hline \multicolumn{5}{|l|}{ Others: } \\
\hline Polygonum amphibium c & $\mathrm{I}-18$ & . & . & . \\
\hline Vinca minor $\mathrm{c}$ & . & . & $\mathrm{I}-18$ & . \\
\hline Solidago virgaurea $\mathrm{c}$ & . & . & $\mathrm{I}-16$ & $\mathrm{I}-<1$ \\
\hline Hieracium pilosella $\mathrm{c}$ & . & II-5 & $\mathrm{I}-<1$ & . \\
\hline Anthoxanthum odoratum c & . & II-5 & . & $\mathrm{I}-5$ \\
\hline
\end{tabular}

The species occurring in the I constancy class and the coverage factor below 10: I. Calamagrostis arundinacea c (1, 3, 4), Convallaria majalis c (1), Dicranum scoparium d (3, 4), Epilobium montanum (1-4), Luzula pilosa c (4), L. sylvatica c (4), Melampyrum nemorosum c (3), Monotropa hypopitys c (2), Mycelis muralis c (1, 2), Pyrola rotundifolia c (2), Quercus petraea a (1, 2); II. Ajuga reptans c (3), Asarum europaeum c (1), Calamagrostis canescens c (2), Campanula persicifolia c (2, 3), Corydalis cava c (1), Corylus avellana b (1), Crataegus monogyna b (1), Equisetum sylvaticum c (1), Festuca gigantea c (1), Ficaria verna c (1), Fraxinus excelsior b (1), Hepatica nobilis c (1,3), Humulus lupulus c (1), Hypericum perforatum c $(1,3)$, Hypnum cupressiforme d (3), Hypocenomyce scalaris d (4), Isopyrum thalictroides c (1), Larix decidua a (4), Luzula luzuloides c (3, 4), Lycopus europaeus c (3), Malus sylvestris a (1), Padus serotina b (4), Paris quadrifolia c (1), Petasites albus c (1), Poa nemoralis c $(1,3)$, Polygonatum odoratum c (1), Pulmonaria obscura c (3), Ranunculus lanuginosus c (1-3), $R$. repens c (1), Rubus plicatus b (4), Salix alba a (1), Scrophularia nodosa c (3), Solanum dulcamara c (14), Stachys sylvatica c (1), Stellaria nemorum c (2, 4), Symphoricarpos albus b (1), Taxus baccata b (4), 
Tussilago farfara c (1), Viola reichenbachiana c (1, 3); III. Centaurium umbellatum c (1), Epilobium angustifolium c (1, 2, 4), Omalotheca sylvatica c (1-3), Senecio sylvaticus c (1, 3); IV. Achillea millefolium c (2), Arrhenatherum elatius c (2, 4), Briza media c (1), Bromus hordeaceus c (2), Cirsium palustre c (1), Cynosurus cristatus c (1), Festuca arundinacea c (1), F. rubra c (1-3), Filipendula ulmaria c (1), Geranium palustre c (1, 3), Holcus lanatus c (1, 2), Lathyrus pratensis c (1, 2), Leontodon hispidus c (2), Lychnis flos-cuculi c (1), Lysimachia vulgaris c (1), Lythrum salicaria c (1), Mentha arvensis c (1), Myosotis palustris c (1), Parnassia palustris c (1), Phleum pratense c (1), Pimpinella major c (1), Plantago lanceolata c (1), Poa pratensis c (2), P. trivialis c (1), Potentilla anserina c (1), P. reptans c (1), Prunella vulgaris c (1), Rorippa sylvestris c (1), Rumex acetosa c (2, 4), Selinum carvifolia c (2), Stellaria palustris c (1), Taraxacum officinale c (1), Trifolium hybridum c (1), T. repens c (1), Vicia cracca c (1); V. Anthriscus sylvestris c (1, 3, 4), Arctium lappa c (1), Calystegia sepium c (1, 2), Cichorium intybus c (1), Cirsium vulgare c (1, 3), Erysimum cheiranthoides c (1), Eupatorium cannabinum c (1), Juglans regia b (1), Lamium album c (1), L. purpureum c (4), Lapsana communis c (1), Malva neglecta c (1), Melilotus alba c (1), Moehringia trinervia c (4), Picris hieracioides c (1); VI. Acorus calamus c (1), Carex acutiformis c (1), Galium palustre c (1), Glyceria fluitans c (1), Phalaris arundinacea c (1), Rumex hydrolapathum c (1), Scutellaria galericulata c (1); Others (Bidentetea tripartiti, Festuco-Brometea, Koelerio glaucae-Corynephoretea canescentis, Nardo-Callunetea, Potametea, Stellarietea mediae, Trifolio-Geranietea sanquinei): Astragalus glycyphyllos c (4), Bromus inermis c (2), Calluna vulgaris c (4), Centaurea scabiosa c (2), Cerastium arvense c (2), Cladonia coniocraea d (4), C. fimbriata d (4), C. macilenta d (1), C. subulata d (1), Dianthus carthusianorum c (2), Equisetum arvense c (1), Erodium cicutarium c (1, 3), Galium mollugo c (1, 3), Hieracium umbellatum c (2, 3), Hottonia palustris c (1), Jasione montana c (2), Lathyrus sylvestris c (1), Lupinus polyphyllus c (1, 2), Luzula campestris c (3), Myosotis arvensis c (1, 2), Nardus stricta c (4), Odontites serotina c (1), Origanum vulgare c (1), Polygonum hydropiper c (1), P. persicaria c (1), Potentilla argentea c (1), P. erecta c (2), Senecio vulgaris c (1), Silene vulgaris c (2), Sonchus asper c (1, 2), Thymus serpyllum c (4), Veronica chamaedrys c (1, 2, 3), Vicia hirsuta c (1), Viola canina c (4).

Cl.: class, O.: order, All.: alliance, Ass.: association; constancy S: I: proportional participation of species $<20 \%$, II: $40-20 \%$, III: $60-40 \%$, IV: 80-60 \%, V: 100-80\%; D: the coefficients of cover (from 1 to 8750 ) were estimated for 10 phytosociological releve's, .: not present; a: trees, b: bushes, c: herbs, d: mosses and lichens; 1-4: information on which surface the species was recorded; min.: minimum values, max.: maximum values, av.: average values 